\title{
Adoption of Human Resources Management Policies for Practices: Harvard Model versus Religious Model
}

\author{
Oginni Babalola ${ }^{1}$, Erigbe Patience ${ }^{2}$, Ojo Afolabi ${ }^{1}$, Laosebikan, 'Sola ${ }^{3} \&$ Ogunlusi, 'Femi ${ }^{3}$ \\ ${ }^{1}$ Department of Economics and Business Studies, Redeemer's University, Ede, Osun State, Nigeria \\ ${ }^{2}$ Department of Business Administration, Oduduwa University, Ipetu - Modu, Osun State, Nigeria \\ ${ }^{3}$ Department of Business Administration, Bowen University, Iwo, Osun State, Nigeria \\ Correspondence: Oginni Babalola, Department of Economics and Business Studies, Redeemer's University, Ede, \\ Osun State, Nigeria
}

Received: November 21, 2017

Accepted: February 14, 2018

Online Published: February 27, 2018

doi:10.5430/bmr.v7n1p51

URL: https://doi.org/10.5430/bmr.v7n1p51

\begin{abstract}
The paper set out to explore two different models of Human Resources Management as a policy for practice that will be adequate for adoption by any organisation. The Harvard and Religious models were the two models critically examined vis - a - vis their implications on the practice of Human Resources Management (HRM). It was revealed that Harvard model of HRM is a content model as it is contingent on specific core issues (work system, reward system, employees' influence and flow of people) in human resources management while Religious model of HRM is a process model as it is based on identification of relationship among components units (management and employees) Harvard model of HRM as a policy is embedded in the organisation through congruence, commitment, cost effectiveness and competence and Religious model of HRM is anchored on value based ideology through morality, honesty, sincerity, fairness and integrity. The two models are practicable but Harvard model of HRM has no exception to a particular party in business organisation while Religious model of HRM is averse to development of trade union in organisation. Therefore, the adoption of the two models will make world of work conducive, however, Harvard model of HRM aligned more with the nature and belief of business. However, combination of the two models to give a contingency - hybrid model will make the workplace to be better than adopting one of the models.
\end{abstract}

Keywords: HRM perspectives, policies and practices, Harvard model, religious model, ten commandments, Contingency-Hybrid model

\section{Introduction}

In response to the dictates of business environment where profit maximization is the prime motive of engaging in business, organisations are now evolving towards workforce stability where supervisor's job is no longer to command but to persuade within available hierarchical structures of authority and responsibility (Drucker, 1999). The implication of this new emergence is that the world of business organisation is moving away from the old longstanding belief that organisation would have cutting edge through access to capital and improved advancement in technology. The change in the management pattern of people at work from the old belief to new a belief was responsible for the movement and change in the name used in the management of these people from personnel management to human resource management (Tyson, 1997; Analoui, 1998 \& 2002; Purcell, 2011; Akindele, Olajide \& Ajayi, 2011; Shawn, 2011).

The people at work or people who make - up an organisation are known as human resources and these people are considered to be sensitive and unique to the success of any business organisation (Esra, 2010). The notion around the sensitivity of human resources with respect to its significance was derived from the belief that management of people at work is a source of sustained competitive advantage as other traditional sources of competitive advantage can easily be imitated (Mabey, Salam \& Storey, 1998; Kakabadse, Kakabadse \& Myers, 1998). Sani (2012) opined that gaining access to capital and technology are no longer tools for sustained competitive advantage because they are easy to imitate by any competing organisations and thus argued that human resource represents asset to give competitive advantage since it cannot be imitated or duplicated by competitors and also substituted within the same. Oginni \& Faseyiku, (2013) views corroborated this and that of Mullins (2002) that unlike other organisational resources that are owned by the organisation, the ownership of people is different. They are individuals who came 
into the organisation with different perspectives, personal feelings and attitudes to the organisation, systems of operations and management styles, what constitute duties and responsibilities as well as under what conditions to perform expected tasks.

However, that part of management that is concerned with the "people management" dimension at workplace is known as human resource management (Deconzo \& Robbins, 1996). McKenzie (2012) describe human resources management (HRM) as the science of managing people at workplace to achieve organisational objectives. Similar to this, was that of Adeoye (2013) where he described HRM as the art and science of managing an organization's resource (people) to achieve specific business objectives, such as high engagement, low turnover, solid satisfaction and other important goals while Flippo (1986) described HRM as management process that is concerned with planning, organizing, directing, controlling of procurement, development, compensation, integration, maintenance and separation of human resources to the end that individual, organisational and social objectives are achieved. Despite series of definitions of HRM, the message is the same and so also is the implication i.e. people that will interact with process and technology for organisation to achieve their objectives (Akindele, 2007). It is therefore evident that success of any organisation in the contemporary world of business somewhat depends on the quality of human resources in the workforce.

The management of people at workplace is through the performance of HRM activities, activities such as recruitment and selection, socialization and integration, job design, training and development, communication and participation, career development and succession plans, performance appraisal and reward systems, employer - employees' relations, retention and job security etc. (Majumder, 2012). These activities are classified as universal but the practice differs from organisation to organisation whether within the same industry or not, whether in the same region or not and also from country to country whether in the sane continent or not. What account for the difference is the uniqueness of each as characterised by local values, beliefs, customs and core values of the business organisations. Practice derives its strength from policy i.e. whatever found in operation as practice is a function of policy adopted and this explains why the paper set to examine adoption of the Harvard model of HRM and Religious model of HRM as a policy for practice.

The adopted HRM policy for practice should be meaningful towards realization of the overall objective of the organisation which should be modified to reflect societal and organisational differences such that a favourable atmosphere, condition and culture conducive for attainment of mission as well as getting employee's loyalty, trust and reduction in labour turnover, appreciable level of satisfaction are put in place in order to get them committed to the organisation. This was evident in the position of Armstrong (2009) that the practice of HRM adopted in an organisation will influence employee's knowledge, skills, abilities and attitudes as well as behaviours i.e. intention to leave, levels of job satisfaction, organisational performance and competitiveness, commitment and loyalty, organisational integration and quality of work. Since human resource in the organisation has been seen as resource that cannot be imitated, source of competitive advantage, determinant of success or failure of an organisation and not owned by the organisation, it is therefore, imperative to focus on the HRM policies adopted for practices in order to meet individual, organisational and societal objectives. The rationale behind this is that today, organisations employ qualified workforce that are more educated in history of workplace where employees have high salary expectations, opportunities to participate in organisational decision making, desire to have fair treatment with dignity and respect, assessing the effect of work demands and working hours on their families as well as personal lives. (Burke \& Eddy, 2000; Jackson, Schuler \& Werner, 2012).

\subsection{Human Resource Management - Policies and Practices}

For the expected performance of work to be uniform and conform to standard, there must be a sort of policy in place to serve as yardstick for measuring the desired objectives. To Drucker (1989) organisation through policy can translate the goals of organisation into achievable objectives because policy is a general guide to action that will help in the attainment of objective. Rigby (1998) opined that policy is translated into rules, plans and procedures as it is related to all the activities of an organisation at all levels. Similar to this was the view of Wei (2006) that policy can help to reinforce the main functions of an organisation, make case for consistency and reduce dependency on the actions of individual managers. Bruce (2001) asserted that policy clarifies the roles and responsibilities of managers and other members of staff as well as providing guidelines for managerial behaviour.

A human resource policy can therefore be described as a guiding principle in the functional areas of decision making on matters relating to management of people in the workplace. The policy would aid specific decisions relating to employee's treatment either as an individual or group of individuals. However, the cardinal focus of any human resource policy should be concerned with effective utilisation of human resources with respect to performance of 
HRM activities to achieve predetermined organisational objectives. The essence of human resource policy is to facilitate smooth performance of HRM activities by exhibiting appropriate behaviour that would ensure accomplishment of assigned tasks within the specified period of time through the use of available physical resources (Torrington \& Hall, 1998; Whitener, 2001).

Evolving from the human resource policy is the guiding phenomenon for management of people in the workplace known as 'practice'. Therefore, the performance or implementation of personnel policies is known as 'Human Resource Management Practices' i.e. the ways and manners by which all the activities in the human resources management are being carried out is known as the 'human resource management practices'. Fadiora (2012) explained that HRM practices as those activities of human resource management that have empirical evidence and theories relating to the organisation performance. Oginni \& Faseyiku (2013) opined that human resource management practices can be described as the process of developing, applying and evaluating policies, procedures, systems and methods as well as programs relating to the employment relationship in the workplace. Therefore, the kind of human resource policy found to be in operation at any given time would definitely determine the nature of human resource management practices (Fajana, 2002). The views of Fadiora (2012) on HRM policy and practice was summarized to focus on perception and image i.e. how employee perceives their organisation emanate from the practice of HRM found to be in operation at any time in the development of the organisation and evolving from this perception is image. The image would thereafter form the mental picture of what the organisation is all about in the minds of the employees. The earlier work of Snape \& Redman (2010) on HRM objectives and policies, pointed out that perception of employees about the organisation would determine commitment level in terms of loyalty.

\subsection{Perspective to Human Resource Management Practices}

Rose and Kumar (2006) identified three underlining distinctive perspectives that revolve around the practice of human resource management in organisations to be universalistic, contingency and configurational perspectives:

a. Universalistic Perspective: This focus on the best practice of HRM i.e. some HRM practices are better than the others. Therefore, any organisation that encourage the use of best practices will have better results in terms of performances. The following were the seven practices considered as good HRM practices namely internal career opportunities, appraisal, training and development system, profit- sharing plans, employment security, voice mechanism, including formal grievances system together with participation in decision making (Osterman, 1987; Sonnenfeld \& Peiperl, 1988). Despite its criticism that the perspective overlooks some jobs that are narrowly or tightly defined, researchers have supported this approach to HRM practices (Abowd, 1990; Gerhart \& Milkovich, 1990; Leonard, 1990; Terpstra \& Rozell, 1993).

b. Contingency Perspective: This perspective entails that there is need for an organisation to adopt specific human resource management practices for different situations. This must reflect the dictate of the prevailing circumstance, therefore, HRM policies should be consistent with every aspect of the organisation for the policies to be effective and at the same time to elicit appropriate behaviours that are consistent with organisational overall strategies (Rose and Kumar, 2006). For example, Fama \& Jenson (1983) opined that organisations that adopts this approach will motivate employees to behave in a manner consistent the business strategies. This view was supported by Kerr \& Jackofsy (1989). However, Rose (2002) extended his work to the Japanese style of management, she found that the management style of the Japanese lay emphasis on HRM practices because of their belief that employee - based HRM practices can make the workforce to be productive in line with organisation's needs.

c. Configurational Perspective: This perspective focused on how the patterns of multiple, planned and HRM development and activities achieve the organisation's goals. Beckers \& Gerhart (1996) asserted that an organisation should develop HRM practices that meet both horizontal and vertical fit. Horizontal fit refers to internal consistency of the organisation's HRM policies and practices while vertical fit is the congruence of the HRM practices with the organisational features such as organisational strategy. (Miles \& Snow, 1984; Arthur, 1992; MacDuffie, 1995).

\section{Human Resource Management - Harvard Model and Religious Model}

\subsection{Harvard Model of Human Resource Management}

This model of HRM was propounded by Michael, Walton, Quinn, Lawrence and Bert through their book titled Managing Human Assets published in 1984. The theory believed that the kind of HRM policies and practices an organisation adopts should dependent upon the organisational vision, mission, strategy, goals and objectives. The HR practice should be in tune with external environment of the organisation i.e. HR policies and practices are contingent on internal and external environment of the organisations. The model highlighted the influence of environment on the outlook of HRM practices and also known as soft model HRM/ Harvard map of HR or sometimes refers to as 
Multiple Stakeholders model. According to Srinivas (2005), the model based her arguments on the premise that HR policies are influenced by two significant considerations:

i. Situational factors: The internal and external environment factors of organisations serves as major constraints to development of HRM policies such as labour market conditions, societal values, business strategies, technologies, management philosophies and markets conditions.

ii. Stakeholders' interests: The stakeholders influence short- term HRM policies which are not limited to management employees, unions and government agencies.

The premise of Harvard model was based on four major elements of HR issues as follows:

i. HR flows: The recruitment, selection and placement, promotion and assessment, termination and the likes

Reward system: Pay systems, non - monetary recognition schemes, organisational benefits and so on

ii. Employee influence: Clarification of responsibilities, authority, hierarchy and delegation of powers

iii. Work system: Definition of work and alignment of people

To the scholars in this model, the above HR practice is centred on four Cs discussed below:

i. Commitment: HRM policies should contribute and infuse employee commitment to the organisation and such commitment has two benefits i.e. employee's performance and loyalty to their work; individual self - respect and worth.

ii. Competence: HRM policies and practices should be designed in a way that employees with valuable skills and knowledge will be attracted, developed and retained.

iii. Cost effectiveness: HRM policies should be evaluated on the basis of cost - benefit analysis in terms of wages and salaries, benefits (incentives and non - incentives), turnover, absenteeism and strike etc.

iv. Congruence: There should be congruence between and among all HRM policies and practices found to be in operation at any time.

This model will help HR practitioners to develop HR strategies for their organisation and provides three vital insights considered to be important for the practice:

i. HRM policies should be well defined with respect to environmental factors and stakeholder's interest. i.e. there should be a good fit between organisational environment and HR policies.

ii. HRM policies and practices should draw support on how employee's commitment, competence, development and coherence among themselves and embrace cost effective methods.

iii. HRM policies that is contingent upon environmental factors and accommodates the four Cs will experience organisational and employees' effectiveness. It is this outcome that made this model to be referred to as soft model because it is purely based on stakeholders' concerns and their commitment to the organisational objectives.

\subsection{Religious Model of Human Resource Management}

Three different academicians namely Abbas Ali, Manton Gibbs and Robert Camp of the Indiana University of Pennsylvania postulated a model with religious foundation to HR strategy through their work titled 'Human Resource Strategy: The Ten Commandments Perspective' published in the International Journal of Sociology and Social Policy in 2000. To them, religion has and exerts powerful influence over human behaviour as human being carries these religious learning into their respective organisations in a dominant fashion. All religions have basic guiding principles or tenets for mankind to follow whether Christians, Jews and Muslims each has their respective commandments which from time to time influences the outlook and behaviour of individuals and groups (Abbas \& Manton, 1998).

In their analysis, Ten Commandments of God to Moses, the new Ten Commandments propounded by Jesus Christ for his followers and Islam ten virtues of commandment were used as the basis of their arguments wherein HR aspects of ten commandments in the three religion centres on loyalty, networking and minimization of conflict to ensure survival and continuity. The implications of each of the Ten Commandments were given below in tabular form starting with that of Jesus Christ to Islam and that of Moses. 
Table 1. The New Ten Commandments propounded by Jesus Christ and their implications

S/N Ten Commandments Implications

1 You have heard that it was said by them of old time. That thou shall not kill; and whosoever kills shall be in danger of judgement. But I say unto you that whosoever that is angry with brother without a cause shall be in danger of the judgement.

2 You have heard that they said of it of old time. That thou shall not commit adultery; But I say unto you that whosoever looketh on a woman to lust after her hath committed adultery with her already in his heart.

3 It hath been said that whosoever shall put away his wife let him give her a writing of divorcement; but I say unto you that whosoever shall put away his wife, saying for the cause of fornication, causeth her to commit adultery and whosoever shall marry her that is divorced commit adultery.

4 Swear not at all, neither by heaven for it is God's throne.

Manager should create an environment that is conducive for harmonious relationship; conflict is a threat to group survival; due process enhances confidence and trust.

Management and employees should observe the spirit and framework of their contract, sincere and honest relations are valid for a spirit of team work.

Management should treat employees with fairness; management should not be motivated by mere short-term cost reduction in conducting its strategies.

Employees should trust management and not resent its instructions.

5 Ye have heard that it hath been said, an eye for an eye and tooth for tooth; but I say unto you that ye resist not evil; but whosoever shall smite thee on thy right cheek turn to him the other also.

6 Ye have heard that it hath been said thou shall love your neighbour and hate your enemy; but I say unto you that love your enemies, bless them that curse you and do good to them that hate you, pray for them that despise and persecute you.

7 That ye may be the children of your father which is in heaven; for He maketh His sun to rise on the evil and on the good and sent rain on the just and the unjust.

8

For if ye love them that love you, what rewards have ye? Do not even the republican do the same?

9 And if he salutes you brethren only, what do ye more than others? Do not even the republican so?

10 Be ye therefore perfect, even as your which is in heaven is perfect
Employees should tolerate management even when affairs are carried out in an authoritarian style; employees should avoid conflicts among themselves and with management.

Tolerance for some abuse power is vital for group and organisational survival. Resentment in the work place may lead to severe consequences.

Management should treat employees equally and reward them as such. Interactions between management and employees need to be just and equitable for building trust.

Management should reward employees that are loyal and productive; fairness in conduct and tolerance for diversity strengthen the culture of the organisation.

There should be no discrimination in the workplace; employees should be motivated to their best as a team and be an example for new recruit to follow.

Management should be model that inspires employees to achieve perfection in their work. 
Table 2. Ten Commandments in Islam and their implications on human resource practices

\begin{tabular}{ll}
\hline S/N & Ten Commandments \\
\hline 1 & Do not consider anything equal to God \\
2 & Be kind to your parents. \\
3 & $\begin{array}{l}\text { Do not murder your children out of fear of } \\
\text { poverty }\end{array}$ \\
4 & $\begin{array}{l}\text { Do not even approach indecency in the public or } \\
\text { in the private life. }\end{array}$ \\
5 & $\begin{array}{l}\text { Do not murder for no reason any one whom God } \\
\text { has considered respectable. Thus, your Lord } \\
\text { guides so that you may think. }\end{array}$ \\
6 & $\begin{array}{l}\text { Do not handle the property of the orphans } \\
\text { except with a good reason until they become } \\
\text { mature and strong } \\
7\end{array}$ \\
Maintain equality in your dealings by means of \\
measurement and balance.
\end{tabular}
Implications

Respect for competent leadership; priority in hiring should be given to qualified individuals.

Disagreement with the superior should be voiced politely; employees should follow the instructions of their superior.

Management should consider employee layoff and downsizing as the last resort to maintain business survival.

Employees should be honest in dealing with the management and should not sabotage property; management should show utmost consideration for social morals, values and the rights of employees

Management should establish a due process for dealing with employee's grievances and should show justice and equity; performance should be the main criteria for evaluation.

Management should not abuse the rights of employees. Employee pension funds should be handled with utmost care.

Management should be fair and just in recruiting, in giving compensation and in the treatment of employees. Management should maintain a balance programme to motivate and retain employees; employees should do their best to meet their commitment to their respective organisations.

$8 \quad$ Be just in your words even if the party involves should be your relatives

9 Keep your promise with God. Thus your Lord guide you so that you may take heed

Management should avoid favouritism and nepotism; there should be no discrimination in the work place; supervisors should avoid misleading their subordinates; maintaining the dignity of employees is a virtue, diversity is for organisational growth.

Employees should observe both the letter and the spirit of their agreement with their organisations and should not violate any term of agreement that would harm the organisation.

10 This is my path and it is straight. Follow it and not other path which will lead you far away from God.

Management should device plans that motivate employees to be productive and loyal to their organisations; frankness in dealings with subordinate is a virtue. 
Table 3. The Original Ten Commandments given to Moses by God and their HR implications

\begin{tabular}{ll}
\hline S/N & Ten Commandments \\
\hline 1. & Thou shalt have no other gods before me.
\end{tabular}

2. Thou shalt not make unto thee any graven image, or any likeness of anything that is in heaven above, or that is in the water under the earth.

3. Thou shalt not take the name of Lord thy God in vain; for the lord will not hold him guiltless that taketh his name in vain.

4. Remember the Sabbath day. Six days shalt thou labour, and do all thy work. But the seventh day is the Sabbath of the Lord thy God; in it thou shalt not do any work, thou, nor thy son, nor thy daughter, nor thy man servant, nor thy maid servant, nor thy cattle, nor thy stranger, that is within thy gates.

5. Honour thy father and thy mother

6. Thou shalt not kill.

7. Thou shalt not commit adultery

8. Thou shalt not steal

9. Thou shalt not bear false witness against thy neighbour

10. Thou shalt not covet thy neighbour's wife, nor his manservant, nor his maidservant, nor his ox, nor his ass, nor anything that is thy neighbour's

\section{Implications}

Centrality of authority and leadership in organisational life. Leaders play a vital in motivating employees and enhancing the cohesiveness of the group.

Employees should be proud of their work and be loyal to authority; rewards are for those who obey and observe instructions.

Employees should be respectful of their leaders and be loyal to them.

Flexible work schedule enhances commitment, group retreats are vital for spiritual renewal and commitment; leisure activity should be encouraged as it provides refreshment of energy and motivation.

Employees should respect management and be loyal to their organisation: they should honour their organisational contracts.

Employee should not resort to violence to enforce their demands.

Management and employees should honour their contracts; both should not disturb work group norms and established procedures.

Management and employees should not abuse organisational resources; sincerity to work groups increases turnover and enhances productivity.

Employees should not provide false information that might demoralize their organisation. Management and employees should negotiate in good faith.

Management should not layoff employees just for the sake of it; neither management nor employees should pursue any desire that would weaken organisational cohesiveness.

Sources: Srinivas R. Kandula (2005). Human Resource Management in Practice with 300 models, techniques and tools, New Delhi, Prentice - Hall of India Private Limited; and

Abbas J. Ali \& Manton Gibbs, (1998). "Foundation of business ethics in contemporary religious thought: The Ten Commandment perspective", International Journal of Social Economics, Vol. 25 (10), 1552-1564.

The implication of these religious commandments is that the ultimate philosophy of any HR strategy should be similar to that of Ten Commandments - morality, honesty, sincerity, fairness and integrity in order to gain employees' commitment to the priorities of the organisation. It may be easier to drive these points with the help of religious principles as members of these sects held the tenets of their beliefs without questioning the rationale behind their faith or belief. A model of HRM integrating all the three religious commandments could be drawn to attain workforce commitment if the model is adopted as a philosophy for practice by organisations. The practical objective of such a model should be to relay message in a language that will not distort the information, at the same time to encourage mutual respect on the part of employees and employers and pursuant of integrity with great passion (Srinivas, 2005). 


\section{Discussions}

The Harvard model of HRM practices is a content model of practice as it is contingent on those specific things that are actually the core issues in human resources management and can be applied to any type of organisation whether the organisation is large scale or small scale, be it a unionized organisation or not, be it the management style adopted and be it a growing or declining business.

It is concerned with situational factors and the stakeholders' interest and thus ensures that there is a balance in the interest of all parties to activities in workplace through work system that enable arrangement of people and technology, activities and information throughout the organisation. It is a belief that this arrangement will make the work to carried out in an effective and efficient way; Reward systems regulate how employees are extrinsically and intrinsically rewarded for the work done. Extrinsic rewards are holiday entitlement, benefits, pensions, flexible working hours, overtime pay, wages and salary while intrinsic rewards are promotion, recognition, self - esteem, challenges, work itself, achievement, involvement, self - confidence, respect and dignity, sense of purpose and satisfaction.

The model opined that employees should be involved in the design process reward systems of the organisation which should be consistent with management philosophy, business strategy, HRM policies and meet employees' needs; Manager and HR specialists should work together and ensure flow of people in the organisation in order to meet its strategic requirements. i.e. the engagement of people into and disengagement of people out of the organisation. This revolve around recruitment, selection and placement, termination of employment and promotion, job security, training and development, fair treatment, career development and advancement. The last of this, is employee's influence that dwells on the degree of variance in power, responsibility and authority at the disposal of employees under delegation voluntarily in accordance with management's purposes and priorities. The relevance and significance of the model is further strengthened by the four $\mathrm{Cs}$ of the model i.e. competence, cost effectiveness, congruence and commitment which serves as basis for benefits in the long run because they are strategically linked with organizational objectives. Aside this, It also helps the organisation and employees to grow simultaneously as well as focusing on creation of healthy employment relationships in order to herald an enduring atmosphere for a sustainable business model over a long period of time. However, the model ignores that likelihood of business failures; organisational challenges leading to poor productivity and social loafing process causing conflicts at workplace. In addition, it does not understand factors relating to business and economies.

Religious model of HRM at workplace does not mean religion at work because religion at work means so many things to so many people but religion is often seen an important aspect of a person's identity. Religious model of HRM is a process model as it is based on identification of relationship among components units in the organisation especially management and employees of an organisation. It showed what an organisation will benefit if religious requirements can be inculcated into human resources management practices with focus on value management (morality, honesty, sincerity, fairness and integrity) as enshrined in religious practices which are readily acceptable to people in the world; the model also based its approach on concept of good conduct that is universal throughout the organisation in order to improve efficiency and effectiveness of all operations carried out in the organisation; and at the same time, enhance the level of compliance and confidence of the workforce. The strengthen of Religious model of HRM practice in the workplace is the focus on team building by creating awareness about tenets of religious values and how to maximise staff retention through staff cohesion as well as understanding the boundaries acceptable from their perspective (HR department, employers and employees) and what is potentially damaging to the business. In addition, the model does not really make provision for development of trade union which might serve as a watch dog against mismanagement of both human and materials resources simply because every employee is expected to be fairly treated and fairly compensated. In the same vein, the presence of union sometimes does not allow the business to get rid of bad or unproductive employees due to union tendency to protect all the employees whether productive or not - a tendency that offset whatever benefits a union might likely provide.

\section{Conclusion}

In view of the two positions, which of the models will be in the best interest of a business organisation as a policy for practice? Business is all activities that are concerned with production and distribution of goods and services for the satisfaction of human kind profitably (Oginni, 2014). Therefore, the focus of business here is to ensure that the process of conducting business is such that production and distribution of goods and services satisfy customers' needs and at the same time, to meet the profit motive of stakeholders. The practice in most business organisations is to treat management team as 'semi god' or accustomed to 'playing god' and other employees seen as another column of numbers on a balance sheet which is not in accordance with the principles of religious model of HRM, therefore, the Harvard model of HRM as a policy for practice has grater alignment with the nature of business although 
adoption of religious model of HRM as a policy for practice in the world of work would have made the workplace a better conducive atmosphere. It will therefore be expedient to say accommodation of the religious model of HRM along with the Harvard model of HRM as a policy for practice in the world of work will make the workplace to be the best. The end result of such will be hybrid model of HRM to be known as contingency - Hybrid model i.e. treating employees as machine when the need arises and as not machine by working on emotions that will enhance employees' motivation, job satisfaction, and organisational commitment when the need also arises. i.e. a Contingency - Hybrid model.

\section{References}

Abbas J. Ali \& Manton Gibbs. (1998). Foundation of business ethics in contemporary religious thought: The Ten Commandment perspective. International Journal of Social Economics, 25(10), 1552-1564.

Akindele, R.I, Olajide, O.T \& Ajayi, M.O. (2011). Strategic Human Resource Management Practices on Organisation Performance of Selected food and beverages Industries in Nigeria: An empirical cultural position, Journal of Business, 16(2), 168-176.

Abowd, J. (1990). Does Performance-based managerial compensation affect corporate Performance? Industrial and Labour Relations Review, 43, 52-73

Adeoye Olufemi David. (2013). Personnel Management or Human Resources Management, Lagos, Edet Publishing House.

Analoui, F. (1998). Human Resource Management issues in developing countries, Eds Aldershot, Ashgate.

Analoui, F. (2002). The Changing Patterns of Human Resource Management, Eds Aldershot, Ashgate.

Armstrong, M. (2009). A Handbook of Human Resource Management Practices $11^{\text {th }}$ ed. London, Koganpage Limited.

Arthur, J. (1994). Effects of Human Resource Systems on Manufacturing Performance and Turnover, Academy of Management Journal, 37, 670 - 687.

Becker, B. and Gerhart, B. (1996). The impact of Human Resource Management on Organisational Performance: Progress and Prospects, Academy of Management Journal, 30, 779-801.

Bruce, D. (2001). Help wanted: Results of the CFIB survey on the shortages of qualified labour, Canadian Federation of Independent Business.

Burke, R.J. and Eddy, N. (2006). The changing nature of work and organisations: Implication for Human resource management, Human Resource Management Review, 16, 86-94.

DeConzo, D.A. and Robbins, S.P. (1996). Personnel / Human Resource Management, $3^{\text {rd }}$ ed. New Delhi Prentice-Hall of India Pvt Ltd.

Drucker, P.F. (1989). The Practice of Management, USA, Heinemann Professional.

Drucker, P.F. (1999). The shape of things to come. In F. Hesselbein and P. Cohen (ed). Leader to leader: Enduring insights on leadership from the Drucker Foundation's award-winning Journal, 109-120, San Francisco, CA: Jossey-Bass.

Esra N. Caliskan. (2010). The Impact of Strategic Human Resource Management on Organisational Performance, Journal of Naval Science and Engineering, 6(2), 100-116.

Fadiora, R. Gbolahan. (2012). Impact of Human Resource Management Practices on Organisational Performance in Nigeria: An Empirical Study of Eco bank Nigeria Plc in the last five years, International Journal of Contemporary Business Studies, 3(10), 43-62.

Fajana Sola (2002). Human Resource Management: An Introduction, Macmillian Publisher, Lagos.

Fama, E.F., \& Jenson, M.C. (1983). Separation of Ownership and Control, Journal of Law and Economics, 26, 303-325.

Flippo, E. B. (1986): Personnel Management, 5th edition, London, McGraw - Hill Book Co Ltd.

Gerhart, B., and Milkovich, C.T. (1990). Organisational differences in the Managerial Compensation and Financial Performance, Academy of Management Journal, 33, 663-391.

Jackson, S.E., Schuler, R.S., \& Werner, S. (2012). Managing human resources, 11th ed. Mason, Ohio: Cengage. 
Kakabadse, A., Kakabadse, N. and Myers, A. (1998). Demographics and Leadership philosophy: exploring gender differences, The Journal of Management Development, 17, 351-388.

Kerr, L. and Jackofsy, E.F. (1989). Aligning managers with strategies: Management Development versus Selection, Strategic Management Journal, 10, 157-170.

Leonard, J.S. (1990). Executive Pay and Firm Performance, Industrial and Labour Relations Review, 43, 13-29.

Mabey, C., Salaman, G. and Storey, J. (1998). Strategic Human Resource Management, London, Sage Publication.

MacDuffie, J.P. (1995). Human Resource Bundles and Manufacturing Performance: Organisational logic and flexible production systems in the world auto industry, Industry and Labour Review, 48, 197-221.

Majumder, M.T.H. (2012). Human Resource Management Practices and Employees' Satisfaction towards private Banking Sector in Bangladesh. International Review of Management and Marketing, 2(1), 52-58.

McKenzie, K. (2010). Organizational Culture: An Investigation into the link between Organizational Culture, Human Resource Management, High Commitment Management and Firm Performance, Otago Management Graduate Review, 8(5), 231-239.

Miles, R.E. and Snow, C.C. (1984). 'Designing Strategic Human Resource System', Organisational Dynamics,13, 36-52.

Oginni Babalola O (2014). Business Organic Management, $3^{\text {rd }}$ ed., Lagos, Colmar Concept.

Oginni, B.O. and Faseyiku, I.O. (2013). Fundamentals of Human Capital Management: A process approach, $2^{\text {nd }}$ ed., Mankore Print Ltd, Somolu - Lagos.

Osterman, P. (1994). How common is workplace Transformation and who adopts it? Industrial and Labour Relations Review, 47(2), 173-188.

Purcell, J (2001). 'The meaning of strategy in human resource management', in J Storey (ed) (2001), Human Resource Management: A Critical Text, $2^{\text {nd }}$ ed, Thompson Learning: London, 59-77.

Rigby, R. (1998). 'Mission Statements' Management Today, March, 36-58.

Rose, R.C. (2002). Japanese - Style Management abroad, Kuala Lumpur, Prentice Hall.

Rose, R. Che and Kumar, N. (2006): The Influence of Organisational and Human Resource Management Strategies on Performance, Journal of Performance Improvement, 45 (4), 18-25.

Sani A. Danlami (2012). Strategic Human Management and Organisational Performance in Nigerian Insurance Industry: The impact of Organisational Climate, Business Intelligence Journal, 5(1), 8-20.

Shawn, A Smith (2011). The HR Answer Book: An Indispensable Guide for Manager and Human Resources Professionals, NY, Amacom.

Snape E., \& Redman, T., (2010). HRM practices, organizational citizenship behaviour, and Performance. Journal of Management Studies, 47, 1219-1247.

Sonnenfeld, J.A. and Peiperl, M.A. (1988). Staffing Policy as a strategic response: A typology of Career systems, Academy of Management Review, 13, 588-600.

Srinivas R. Kandula (2005). Human Resource Management in Practice with 300 models, techniques and tools, New Delhi, Prentice - Hall of India Private Limited.

Terpatra, D.E. and Rozell, E.J. (1993). 'The Relationship of Staffing Practices to Organisational Level Measures of Performance', Personnel Psychology, 46, 27-48.

Torrington, D., Hall, L. (1998). Letting Go or Holding On: The Devolution of Operational Personnel Activities, Human Resource Management Journal, 8, 41-55.

Tyson, S. (1997). Human Resource Strategy, NY, Pitman Publishing House.

Walton, E. Richard (1985). "From control to commitment in the Workplace, Harvard Business Review, March-April.

Wei, L. (2006). Strategic Human Resource Management: Determinant of Fit, Research and Practice in Human Resource Management, 14(2), 49-60.

Whitener, E.M. (2001). Do "High commitment human resource practices affect employee commitment?" A cross level analysis using hierarchical linear modelling, Journal of Management, 27, 515-535. 